\title{
Development of Administrative Management for Charity School in Buddhist Temples
}

\author{
Phramaha Thanasak Thammachoto (Cheunsawang) ${ }^{1}$, Phrakru Wilardkanchanadhamma \\ (Lek Sudhammapanno) $^{2}$, Phrakruwirojkanchanakhet ${ }^{3}$, Lampong Klomkul ${ }^{4}$ \\ ${ }^{1,2,3,4}$ Faculty of Education, Mahachulalongkornrajavidyalaya University \\ ${ }^{1}$ Sudjai.mt1@gmail.com, ${ }^{2}$ suthamma_2548@hotmail.com, ${ }^{3}$ wit9195@hotmail.com, ${ }^{4}$ research.mcu@gmail.com
}

\begin{abstract}
This academic article was to propose the development of administrative management for charity school in Buddhist temples. This paper was written from area studies in the collaborative activities in schools and communities cooperated with 3 organizations consisted of home, temple and school in friendly for sustainable coordination. These three harmonize together in a manner that was known as being born from the mind who wants to participate in a particular activity in order to affect the needs of people in line with the social way of life. Therefore, providing the community enter to truly get involved of participation activities need to be considered lifestyle, noble values, culture and attitude for voluntarily participate in community-based activities that supported by public schools and temples. The religious training team advises personnel, students and community members to gain sustainable morality. Mission of great importance is that the school administrators must be able to lead the organization to survive and must set a plan and method as well as various steps in operating systematically by relying on the budget and resources from the state that needs to use with saving and wisely including people, money, time and other assets. If the administrative system within the school is not good, it will affect other parts of the organization. Therefore, success or failure in the school administration will depend on the competency of the school administrators.
\end{abstract}

Keywords

Administrative Management, Charity School, Buddhist Temples

Article Received: 10 August 2020, Revised: 25 October 2020, Accepted: 18 November 2020

\section{Introduction}

At present, the school is an institution of society that arising from the needs of society to perform the main duty of organizing teaching and learning activities for members of society by educating and teach to develop people to flourish, have knowledge, ability, morality, morality, good culture. They are honest, selfless, and willing to train together in various missions for the benefit of society as a whole, education is the process of learning what happens to all life and is also a process of transferring knowledge and culture. This can be said that it is a process by which people develop their abilities in terms of attitude and behavior according to social values, as well as the process of transferring knowledge, both ordinary and professional, moral and cultural. The key is an indication of the conduct and use of knowledge to benefit society as a whole, which is a good attitude of kindness which treats the public in a good way. It gives rise to skills, fluency, and expertise to follow in appropriate way according to the moral scope, both external conduct and internal virtue are important. Administration is a process of working with people and by people. That is not successful because of people due to there is no way to behave to have adequate spending. If they are in a relationship, they will not suffer and commit any corruption. When he knows how to live his own life well, would inevitably be widespread in those around him, able to help, can support others, participation in the community will be able to make society, and the community is only generous, generous, or is the principle of mutual aid. There is alms that is the sacrifice or the generosity of sharing of oneself for the benefit of others, not stingy, not a single person. This virtue will help you to avoid being greed, not selfishly speaking is speaking with sweet words. Sincere do not speak rude and aggressive say what is helpful, suitable for the time. The Lord Buddha places great emphasis on speech. Objectivity is all kind of relief or behavior that is beneficial to others. Samanattata is to be consistent or always having behavior that is consistent treat other people equally appropriate to the status quo. [2]

In the academic year 1977, the Office of the Private Education Commission has issued a policy and work plan in accordance with the National Education Act, 1977, therefore, added the educational development policy in terms of quantity to promote the organization of a nongovernmental charity school for the academic year 19781980, the Office of the Private Education Commission has brought such proposals to work on the development trial project of the temple's public school for charity by having selected schools in different regions, 11 schools are participating in the program, including Phutthamongkolnimit School, Saman Khun Wittayatan School, Suwan Rangsalit Wittayalai School, Wat Ban Pong Samakkhi Khunupatham School, Wat Mai Krongthong Secondary School, Wat Mahaphuttharam School, Winit Suksa School, Phayuha Wittaya School, Phuttachinarat Phitthaya School, Thammarat Suksa School, and Phinit Prasat School by establishing Council of the Government School of the temple for Charity first ascent with the Dharma of Yan Munee Licensee Winit Suksa School elected as the first chair of the council [3].

\section{Development Of The Temple Charity School}

The temple charity school in Buddhism is considered an alternative which was allowed to set up a school under the 
Private School Act B.E. 2488, which has arranged the same teaching and learning as the ordinary school, while having a focus on wanting students ethical. It has a purpose [4] aimed at enhancing knowledge and understanding of principles which lead to correct conduct of Buddhist principles and activities by controlling body, speech and mind within the framework of good morality, ethics and culture. They do not persecute themselves and others, able to benefit themselves and society, as well as have the characteristics of leadership and good followers to maintain themselves as good citizens in society. In a democracy with a monarchy at the same time the school has been supported from the Sangha, which allows the temple monks and communities has entered a full role in education management with the Ministry of Education promoted and give special subsidies to the school because the temple charity school in Buddhism is a model school of education management to the person who cannot be self-sufficient, unattended or disadvantaged [5]. In the academic year 1977, the Office of the Private Education Commission has issued policies and plans in accordance with the National Education Act, 1977, therefore, added the educational development policy in terms of quantity will especially promote the organization of a non-governmental charity school Temple Charity School in Buddhism. It was developed to be a progressive and a school of much higher quality, Office of the Private Education Commission, in particular, providing support to 100 percent according to the guidelines of the tuition fee subsidy card make the temple charity school in Buddhism have guarantees for financial security from the state to some extent. However, the development of the temple to make charity schools in Buddhism has made sustainable progress to hope only the support from the budget that is subsidized alone is not enough. School administrators and teachers who perform school work are also required to have concepts and principles of work in line with social and global needs. Therefore, the school development can be successful.

\section{Concept Of School Development}

The history of the word development, when considered, can be found that is a trend of prosperity in the west or developed countries have flowed to underdeveloped countries or countries less advanced than the word development has been used to describe progress on par with western countries which has a meaning covering many aspects. It is not understood the same in each country at different times. We will find that in the early stages of adopting the development concept used to emphasize economic growth. The transformation to a modern state or industrial adaptation is a formulation methods and strategies for developing the country are different. The concept of development encompasses economic, social, political and cultural aspects. Development should be meant to make the lives of people happy comfort well-being development of arts, culture and mind and peace which in addition to being subject to exposure to material factors to meet physical needs. People still want to be developed in education, good environment recreation and development of various cultures and mindsets, all these needs are sometimes called "Quality development" to show that development is not only dependent on increasing the quantity of products or income.
If it is more than satisfying the happiness of the people [6]. Development is a process that there must be elements of important indicators and must be integrated, including [7]:

1. There is a positive change, including always improving the economy and quality of life. If negative changes are not considered development. It is a change that has to be better, more prosperous, more work and must involve the four pillars: people, structure, technology and systems or jobs including the environment.

2. Changes must be controlled the direction of change can be defined by a clear plan and lead to action that is clearly targeted and can be flexibly adjusted according to the circumstances and time of change convert to with the focus of being developed by the people for people and is a sustainable development.

3. The result of that development equity and new distribution must be created (redistribution) in the fair distribution of income and distribution of justice in terms of quality of life (Quality of Life) to people in the society fairly must achieve true equality in opportunities (education, work, progress, etc.).

Planned or directed change, that is, development is not natural if it is human efforts to bring about change. By determining the direction or details in advance of what to develop, how to develop, how fast, how fast who will be the developer and who will be developed?

Development is the process of changing and improving the quality of life of the majority of people for the better. This includes matters that determine the value of people in each society. Therefore, the meaning of development varies over time. Location and nature of problems or needs of each society. The factors that support the change to be in a desirable direction are as follows [8] :

- It's a change that brings improvements for most people.

- It should be as dangerous as possible and beneficial to everyone, at the very least, that it should be able to meet the basic needs or desires needed for sustaining life.

- It is consistent with the needs of most people and does not destroy the environment.

In a fundamental sense of development is to bring about change in all areas of society. Development is not only income or economic development, nor is it technical, but development is a change in concept and change in action for the better. This is a change to meet the needs and bring about a better quality of life of all people.

\section{School Administrative Manament}

Administration refers to the activities in which two or more people cooperate with each other to achieve one or more of the objectives jointly defined by individuals, using a systematic process and appropriately providing resources and techniques [9]. Managing is to bring a group of people in an organization to work together to achieve the common objectives of the organization. Management consists of planning, organization management, selection of personnel directing, and to control the organization or its efforts to achieve common objectives. Resource management consists of the use and placement of human resources. Financial resources, technology resources, and the shared natural resources of the group of people. 
School refers to the legal body that has duties or have an objective in organizing education. Whether it belongs to the public or private sector the school administrators are in charge of the school administration and teacher management to perform the main teaching and learning duties and promote the learning of learners. Each school has an environment, factors, and cultures differ in the administration of education in all schools, administrators are required to study principles, concepts and theories varied to be adapted to suit the school context provide education as a life-long education for the people to allow society to participate in the provision of education, material development, and the learning process is ongoing.

School administration refers to the work process in which the school administration performs a systematic mission in the school it runs. School administration is the process of working by the group of administrators to develop or provide educational services to members of society to meet the course objectives school administrators are therefore important persons who have roles and authority in managing the school to achieve the objectives set by the organization and able to provide educational services to the society as well according to the main mission of educational institutions that the National Education Act B.E. 2542 and the Amendment (No. 2), B.E. with freedom, flexibility and speed.

Administration is extremely important to the operation of an organization. Because it is an important tool to point out success or failure Efficiency or inefficiency of the organization administration is an indication of the progress of society, advancement of various technologies. Management is an important path to advancement, a collaborative nature of group of people in an organization which has ordered. Management must take into account various environmental factors. Executive diagnostics demonstrate the competence of management and the growth of human daily life management, whether in any family or organization of course, it is always involved in the administration, so the management is interesting and necessary for human life in society by virtue of the principle create attitude to make it easier, more convenient, more peaceful, there is peace among many administrators, scholars and educators and has given the meaning of management in many perspectives which can be summarized as follows:

Management generally looks like a process or is the procedure for performing tasks in order of management in which the administration. The list must be listed first what to do first and what to do next, which is considered a scientific methodology (scientific management) management process will determine the scope and functions according to various procedures. It is clearly academic and foreign administrators and educators have given ideas about the administrative process as follows :

The Secretariat of the Teachers Council of Thailand has set standards. The Education Administrators of the Teachers Council of Thailand B.E. 2540 have discussed the guidelines for performing the duties of the school administrators as follows: [10]

1. 1.Perform academic activities related to the professional development of educational administration.
2. Make decisions on activities. It must take into account the impact that will occur on the development of personnel, learners and the community.

3. Strive to develop colleagues to be able to work to their full potential.

4. Develop work plans of the organization to be able to be effective and effective.

5. Develop and apply management innovation until resulting in higher quality results.

6. Performance of the organization with an emphasis on permanent results.

7. A systematic report on the results of educational quality development.

8. Act as a good role model

9. Cooperate with the community and other agencies constructively.

10. Seek and use information for development.

11. Be a leader and build a leader.

12. Create development opportunities in every situation.

Administration is a behavior which is a social process used by administrators to make decisions as a guideline for the management of various departments or organizations. Both public and private organizations achieve the objectives according to the goals by bringing resources to use economically and make the most of in which doing so requires both science and art so that people with different gender, age, educational background, work experience, position, salary, welfare are different. It is not an obstacle to working cooperation, an administrative process. It is a mission that administrators must perform their duties in the sequence of stages of academic administration, personnel, student activities. Administration and finance, premises and relationships between the school and the community. Promoting each other will be a system for efficiency and maximum effectiveness for the organization. The temple charity school in Buddhism was originally called public school of the temple occurs according to the regulations of the Ministry of Education regarding the public school of the Buddhist era in 1941, the temple charity school in Buddhism has encountered a problem in operation throughout, because of the early days are subsidized like other private schools and cannot collect tuition fees from parents of students. Because $95 \%$ of the parents' parents are poor, some schools have to go out of business and some have transferred their businesses to the government (in the past).

\section{Development Of A Temple Charity School In Buddhism To Be Sustainable}

"Education for all people, all people for education", Thailand has always put emphasis on sustainable education development for all. Whether they are Thais, ethnic groups, priests, women, children or even the elderly. Whether they are Thai people by blood or people who come to work or live in Thailand, whether they are entitled to education in the country everyon especially when the National Education Act 1999 and Amendment No. 2 B.E. 2545 stipulated the aim of Thai education that "Education management must be in order to develop Thai people to become complete human beings, body, mind, intelligence, knowledge and morality, ethical and cultural in life, able to live happily with others 
and set the principles of education management as 1 . It is a life-long education for the people (everyone), 2. Engage the society in the provision of education and 3 . The development of the subject matter and learning process to be continuous [11].

These principles reflect the Thai philosophy of providing education for all people. All people for education and is the study or learning continues throughout life by stating that "The provision of education shall provide persons with equal rights and opportunities to receive at least twelve years of basic education that the state shall provide, comprehensively and of quality, free of charge" to be provided by the state with the people in line with the United Nations program above and more importantly, in addition to what the United Nations requires determining the participation of society in the provision of education; It is the distribution of educational power to the people that allow them to play a role in the management of education or support education equally. As Thai people who should take responsibility for Thai education together. Such educational participation is practically reflected in the 1. Establish an education committee at all levels from the policy level. Education area level and educational institutions with representatives of government, private sector, local government organizations, alumni, priests, social institutions and relevant educational qualifications 2. Private Giving Local government organization, family, community, community organization, religious institution, establishment, other social institutions to have the right to provide basic education, having the right to receive academic support receiving state subsidies, and tax exemptions 3. Public education affects the private sector. There must be a public hearing. 4. Providing opportunities for funding and resources for education from all sectors which means that people of all sectors can come to support scholarships and resources for education, various educational institutions 5 . Participation in monitoring the teaching quality of teachers, reflecting to society from time to time by parents.

It can be seen that the direction of education management in Thailand has always been consistent with international. At the same time, it is based on the Thai identity in the context of society, religion, culture, especially the philosophy of sufficiency economy. The process of participation makes Thailand and Thai people have been sustainable until now. Despite having suffered from both the Thai crisis and the world crisis.

\section{Methods And Procedures For The Development Of The Temple Charity School In Buddhism}

1. Participate in thinking schools and learning sources, creating a community of teachers, administrators, school directors, community, stakeholders, acknowledge the problems, needs of learners, parents, guardians, communities, and joint vision of educational institutes for successful educational management.

2. Make decisions when there are activities that require comments, joint decisions affecting the management, stakeholder, interests of learners and the public. Teachers, administrators, school directors and stakeholders will make decisions together on the basis of information about educational institutions and communities. 3. Co-planning, joint operation planning according to the establishment of the community, both formulate a strategic plan, development plan, action plan, and project assignments. and activities meet the needs of the learners and the common community.

4. Join the action when assigning any operation of the school and learning resource, caused by common thinking, plan together the administrators, teachers, educational institutions, and stakeholders have operations in that activity according to the shared mission.

5. Take responsibility when being activities to be performed and results of operations, both positive and negative, the administrators, teachers, school directors, and stakeholders will be responsible for the results that occur together without leaving it to the problem of any one. Such responsibilities are based on the level of responsibilities, such as executives having administrative duties. The teacher is responsible for teaching and provides learning experience, learning development wisdom. Teaches and parents co-introduce monitor the learning of your children. Communities and community organizations are responsible for supporting learning and resource mobilization activities. 6. Co-solve problems when there is a problem arising from the administration or operation of the administrators, teachers, school directors. Stakeholders have ways to find a solution together to accomplish this well.

7. Join in monitoring and evaluation, during and after operation, administrators, teachers, educational institution directors and stakeholders are monitored and evaluated for improvement and development of joint work in learning evaluation activities. Parents can also take part in the assessment of learners.

\section{Conclusion}

The development of the administration of the charity school in Buddhist temples to be successful, school administrators have to study a model in the management of how to develop to reach the goal, to be effective, appropriate to the context and various factors of the school and must understand the work of the organization systematically. For subsystems of internal and external systems of the organization, the development of educational administration is different from the previous studies. It is an administration that can be disclosed to the public and persons with stakeholders involved in all parties for acknowledgment and verifications. It is good for the school that trust will be accepted quality assurance from parents and communities. The current school administration management methods need to be adjusted to focus on development which is consistent with the changing situation. It is necessary that the management, teachers and educational personnel should have knowledge of understanding and develop the school systematically in order to develop students to become perfect human beings, focus on educational excellence, the students will be trained to be good and wise and gives rise to happiness according to the potential development of educational administration. The aims are to achieve good results and achieve the objectives as specified. It is the duty of all concerned persons to know and understand the aims of 
educational management and to work together for the best benefit.

\section{References}

[1] PhD students, Faculty of Education, Department of Management Education Mahachulalongkornraja vidyalaya University

[2] P. Sihapai. Fundamentals of religious and ethical education. Bangkok: Chulalongkorn University Press, 1992.

[3] U. Chani, Office of the temple charity school group in Buddhism, Phinit Prasat School, Muang District Phayao Province. Prachinburi: Intentions, 2010.

[4] Sivarak. Educational Philosophy, Science and Art of Learning Reform, 2nd edition, Bangkok: Ruenkaew Printing, 2002.

[5] P. Reangtrakul, Community involvement in the operation of the temple charity private school in Lampang Buddhism. Bachelor of Education Thesis, Educational Administration: Sukhothai Thammathirat Open University, 2001.

[6] J.Kanjanachitra. Educational institution development. Bangkok: Ramkhamhaeng University, 2005.

[7] N. Kamolsiri Phichaiyaporn. Sustainable development. Bangkok Journal of the Faculty of Humanities and Social Sciences Rajabhat Suan Dusit Institute, 2011.

[8] Phra Dharmapitaka (P.A. Payutto), Quoted in Suthiporn Rattanathorn Sattha, Study of Buddhist sustainable development in the view of Phra Dharmapak (Master's Thesis, Department of Buddhism Office of the Graduate School:

Mahachulalongkornrajavidyalaya University, 2010.

[9] U. Chanthawanich, Guidelines for the administration and development of high quality schools Bangkok: Nam Prik Wan Graphic, 2004.

[10] The Secretariat of the Teachers Council of Thailand. Standard criteria for educational institution administrators. Bangkok:
Printing House, Teachers Council, Ladprao, 1997.

[11] Phra Dharmapitaka (P.A.Payutto). Education and research for the future of Thailand. Bangkok: Phutthatham Foundation. 2009. 